\title{
AGRICULTURA URBANA EM BELÉM DO PARÁ: ATIVIDADE PRODUTIVA, DINÂMICAS SOCIOECONÔMICAS E ORGANIZAÇÃO ESPACIAL
}

\author{
Elvis Albert Robe Wandscheer - UFRGS - Geógrafo e Economista. Mestre em \\ Desenvolvimento Rural. Agualmente Doutorando em Geografia pela Universidade \\ Federal do Rio Grande do Sul - UFRGS. \\ elvishz@yahoo.com.br \\ Rosa Maria Vieira Medeiros - UFRGS - Doutora em Geografia e professora da \\ Universidade Federal do Rio Grande do Sul - UFRGS no curso de Geografia e no \\ Programa de Pós-Graduação em Geografia \\ rmvmedeiros@yahoo.com.br
}

\begin{abstract}
RESUMO
O presente trabalho aborda a agricultura urbana de Belém do Pará. O enfoque da pesquisa contemplou as dinâmicas, organizações e características desta atividade produtiva, uma vez que a mesma tem sido cada vez mais fomentada e visualizada enquanto alternativa de ocupação e renda nos espaços urbanos. Assim, o objetivo do trabalho foi expor a Agricultura Urbana do Município focando sua dimensão espacial e os seus papéis socioeconômicos. A metodologia utilizada foi a análise descritiva com abordagem qualitativa junto à amostra da população das áreas em estudo. A amostra foi aleatória e intencional por abarcar tão somente indivíduos que vivem nos limites urbanos e tem práticas agrárias neste espaço. Os resultados encontrados demonstram diferenciações em função da área e das particularidades locais voltadas para a autonomia na produção, podendo estar mais ou menos atrelada a mercados e mantendo como principais produtos aqueles vinculados à tradição local. As produções são, na maioria produzidos sem produtos químicos. A problemática do transporte se constitui no maior empecilho e em poucos casos houve maior quantidade de mão de obra. De forma geral, pode-se apontar a relevância da atividade num contexto tanto local quanto nacional e mundial de crescimento populacional.
\end{abstract}

Palavras- chave: Agricultura Urbana; Belém do Pará; Atividade Produtiva; Dinâmicas socioeconômicas; Organização Espacial; Produção Agrária no Espaço Urbano. 


\begin{abstract}
The present study approaches the urban agriculture of Belem of Pará. The research focused on the dynamics, organizations and characteristics of this productive activity, which has been increasingly promoted and visualized as an alternative for occupation and finance in urban spaces. So, the aim of this study was to expose the urban agriculture of the city, focusing its spatial dimension and its socio-economical roles. The methodology consisted in a descriptive analysis with a qualitative approach for the population sampled in the study area. The sample was random and intentional, including only the individuals living in the urban limits and having agrarian practices in this space. The results show differentiations related to the area and to the local circumstances facing the production autonomy, which can be more or less coupled to markets and usually maintain as principal products those linked to local tradition. Most of the products are produced without quimical addictives. Problems related to transport constitute the major hamper and in few cases there were greater quantities of workmanship. In general, we can point the relevance of the activity in the local, national and worldwide contexts of population growing.
\end{abstract}

Key-words: Urban agriculture; Belém of Pará; productive activity; socio-economical dynamics; spatial organization; agrarian production in the urban space.

\title{
Introdução
}

O substantivo agricultura desde sua origem e, num processo de transição ainda não findado na atualidade, reportou quase indiscriminadamente ao mundo rural, a produção agrícola, aos espaços nos quais os equipamentos urbanos comumente se apresentam escassos e são ofertados com maiores índices de problemas em sua funcionalidade (seja pelos quesitos qualitativos - da forma de oferta, ou quantitativos em sua distribuição) ou mesmo inexistindo em determinados produtos e serviços.

Entretanto, cabe salientar que a abordagem de rural como alicerce do tradicional, do atraso e da contingência de primeira natureza já a algum tempo (ao menos após a chamada revolução verde) não é debatido administrativa nem academicamente de forma unívoca. Em relação a tal abordagem, existem quesitos que permeiam definições contemporâneas, pois:

Em primeiro lugar, não há setor propriamente tradicional. Toda a economia e toda a sociedade estão penetradas por elementos de modernização, se bem que em diferentes níveis quantitativos e qualitativos. Em seguida, não se pode considerar os dois setores como se fossem separados, independentes ou autônomos [...] (SANTOS, 2009a, p. 27-28). 
Diante desta concepção, a relação urbano-rural é permeada por elementos que se inter-relacionam diretamente. É bem verdade que o debate acerca dessa relação aparece frequentemente a luz de implicações que incidem sobre o campo, sob as quais a pluriatividade $^{1}$ e a mudança na no âmbito das matrizes produtivas, por exemplo, se constituem enquanto tópicos proeminentes. Porém, também coexistem perspectivas nas quais pode-se visualizar uma excessiva crença na expansão material física e cultural da urbanização, no caso brasileiro, conforme Veiga (2003, p. 31): “O entendimento do processo de urbanização do Brasil é atrapalhado por uma regra muito peculiar [...] Este País considera urbana toda sede de município (cidade) e de distrito (vila), sejam quais forem suas características".

Assertivas neste sentido provocam reflexões no sentido de averiguar se, assim como o rural tem-se metamorfoseado, também não permaneceram abrigadas em áreas urbanas atividades, práticas e contextos que muitas vezes mantém, transformam (conservando e adaptando-se) peculiaridades apregoadas comumente a espaços rurais, pois:

[...] a urbanização não é apenas um fenômeno social, ou econômico, ou político, mas também um fenômeno espacial. Como toda e qualquer outra forma de repartição no espaço, é dependente da maneira como os instrumentos de trabalho e os fatores de produção se distribuem. Há portanto, uma relação de causa e efeito recíprocos entre a cidade, como ela se organiza materialmente, e a urbanização, como ela se faz (SANTOS, 2009b, p. 114).

Tão logo, as formas pelas quais se averiguam definições de rural e urbano, a conformação dos lugares se dá em virtude de suas carências e possibilidades. Nesse sentido, em muitos municípios conformam-se espaços dentro dos limites urbanos, espaços agropecuários, seja por necessidade ou demanda advinda da demanda alimentar dos consumidores ${ }^{2}$ (como no caso dos produtos orgânicos, por exemplo).

\footnotetext{
${ }^{1} \mathrm{O}$ conceito de pluriatividade agrícola traz, subjacente, a ideia de uma menor dependência das famílias rurais em relação à agricultura, sendo capaz de mostrar a participação dos membros das famílias agrícolas em atividades exteriores à própria exploração agrícola [...] Os termos "diversificação" e "pluriatividade" podem parecer sinônimos [...] a diferença essencial é que a primeira diz respeito à utilização dos próprios recursos da exploração, e a pluriatividade considera as atividades que independem dos recursos da exploração (SANZ apud PRIEB, 2005, p. 85).

${ }^{2} \mathrm{O}$ consumo, imposto atualmente à população, é ditado pelo sistema de produção. Controlando os meios de comunicação de massa, esse sistema pode impor uma forma predeterminada de comportamento aos consumidores potenciais - isto é, pode distorcer seu perfil de demanda (SANTOS, 2009b, p. 83).
}

Geo UERJ - Ano 14, nº. 23, v. 1, $1^{\circ}$ semestre de 2012 p. 192-222

ISSN: 1415-7543 E-ISSN: 1981-9021

http://www.e-publicacoes.uerj.br/index.php/geouerj 
Essa produção agrárias em espaços pertencentes à cidade é denominada de Agricultura Urbana ou Periurbana (AUP), definida conforme Santandreu e Lovo (2007, p. 11) como:

\begin{abstract}
A AUP é um conceito multi dimensional que inclui a produção, a transformação e a prestação de serviços, de forma segura, para gerar produtos agrícolas (hortaliças, frutas, plantas medicinais, ornamentais, cultivados ou advindos do agro extrativismo, etc.) e pecuários (animais de pequeno, médio e grande porte) voltados ao auto consumo, trocas e doações ou comercialização, (re) aproveitando-se, de forma eficiente e sustentável, os recursos e insumos locais (solo, água, resíduos, mão-de-obra, saberes etc.). Essas atividades podem ser praticadas nos espaços intra-urbanos, urbanos ou periurbanos, estando vinculadas às dinâmicas urbanas ou das regiões metropolitanas e articuladas com a gestão territorial e ambiental das cidades.
\end{abstract}

Também alçado como prática viável como ação(ões) de melhoria da qualidade de vida dos citadinos, ganha fôlego em debates políticos voltados a sustentabilidade. Suas práticas expandem-se enquanto alternativas locais em diversos espaços, possuindo vantagens no circuito inferior $^{3}$ da economia urbana dado o menor percurso da mercadoria do produtor até o consumidor, tornando assim, o produto mais competitivo em parâmetros capitalistas contemporâneos, exceto nos parâmetros quantidade e periodicidade (questões a serem debatidas adiante), já que encontra limitações em termos de área produtiva.

Destarte, o objetivo do trabalho é, diante das reflexões acima expostas, contextualizar e oferecer uma exposição acerca da Agricultura Urbana focando sua dimensão espacial, e os seus papéis socioeconômicos. Para tanto, optou-se pelo município de Belém do Pará ao norte do País, uma vez que o mesmo apresenta diversas situações para análise e reflexões em torno da temática em questão.

Para tanto, a divisão do texto se deu em mais quatro etapas posteriores a introdução e a apresentação de Belém do Pará e as Ilhas Cotijuba e Mosqueiro. Na primeira etapa seguinte estão expostos os percursos investigativos da pesquisa, sua metodologia. A etapa seguinte propõe-se reflexão acerca dos referenciais teóricos, a fim de expor o estado da arte da temática agricultura urbana, bem como de outros referenciais relacionados a mesma. A terceira parte expõe os resultados obtidos no trabalho de campo em Belém do

\footnotetext{
${ }^{3} \mathrm{O}$ circuito inferior da economia seria composto por atividades e serviços não modernos, sendo em geral provido pelo nível de venda e varejo e pelo comércio em menor escala, empregaria assim o trabalho intensivo em lugar da alta tecnologia (SANTOS, 2008).
}

Geo UERJ - Ano 14, n⿳. 23, v. 1, $1^{\circ}$ semestre de 2012 p. 192-222

ISSN: 1415-7543 E-ISSN: 1981-9021

http://www.e-publicacoes.uerj.br/index.php/geouerj 
Pará no estado do Pará, em capítulo constituído por subitens que exponham as reflexões e peculiaridades em questão, para então, no capítulo final, expor nas considerações finais apontamentos e constatações acerca da produção agrária do espaço urbano do município em questão.

\section{O Espaço Urbano de Belém do Pará - Ilhas Cotijuba e Mosqueiro}

O denominado "descobrimento" de Belém do Pará ocorreu no século XVII, tendo a mesma passado por uma gama de modificações no espaço, principalmente no que compete a sua "urbanidade". Assim, as ocupações históricas constituíram os fatores que influenciaram a sua ocupação.

Inicialmente ocupada por espanhóis através do Tratado de Tordesilhas, dado o fato de ser a "porta de entrada" da Amazônia não tardou para chamar a atenção de holandeses, ingleses e franceses. Porém, a ocupação portuguesa extrapola os limites do Tratado de Tordesilhas através dos Bandeirantes, passando assim a haver maior ocupação daquela porção da Amazônia pelos mesmos, tornando-se assim em uma colônia portuguesa (oficialmente confirmada apenas com o Tratado de Madrid 1750). Posteriormente, o ciclo econômico da borracha (1850-1920) passa a conformar uma cidade palco de distintas passagens que levam Belém a ampliação de sua infraestrutura urbana que culmina com processos denominados de "internacionalização" da cidade e a constituição de uma elite local. Porém, com a produção de látex na Malásia, tal ciclo declina vertiginosamente e a sequência de tal processo acaba em estagnação (DIAS e DIAS, 2007).

Cabe salientar, contudo que o processo de urbanização na Amazônia e, não diferentemente em Belém do Pará, apesar de já possuir um espaço urbano desenvolvido (advindo principalmente do período do ciclo da borracha), é observado mais intensamente no período que compreende o pós-1960. Após o chamado boom da borracha, o período que se seguiu de 1920 a $1967^{4}$ compreende um período "em geral considerado como o '[...]

\footnotetext{
${ }^{4}$ [...] a espacialidade da cidade na Amazônia no período compreendido entre 1920 e 1967 se desenvolve pelo encadeamento de continuidades e rupturas, num sistema de ações que em alguns momentos são extraordinariamente dramáticos. Precisamente, esses são marcados pela queda do preço da borracha e pela crise política. Ao mesmo tempo em que os sujeitos se confrontam, a cidade continuou a existir e, por meio deles e com eles, se tornou um lugar de resistência e de experiências ímpares, como o lugar das festas, das criações artísticas, aparecendo como alternativas à vivência urbana (OLIVEIRA, 2010, p. 34).

Geo UERJ - Ano 14, nº. 23, v. 1, $1^{\circ}$ semestre de 2012 p. 192-222

ISSN: 1415-7543 E-ISSN: 1981-9021

http://www.e-publicacoes.uerj.br/index.php/geouerj
} 
período da cidade em crise na Amazônia' (Oliveira, 2003, p. 18). Autores de matrizes metodológicas variadas e, também, de visões de mundo diferentes consideram a cidade nessa região e época como letárgica ou imersa numa crise grande (OLIVEIRA, 2010, p. $33) "$.

O centro do processo de urbanização é acelerado via intervenção estatal, conforme Pereira (2006, p. 24): “[...] O controle da terra, a política de migração induzida e financiada pelo Estado e o incentivo a grandes empreendimentos asseguraram o desenvolvimento da fronteira urbana", relacionando-se intimamente a iniciativas nacionais. Assim,

\begin{abstract}
Objetivando a interiorização da vida política e econômica do Brasil, o Presidente criou no Planalto Central a nova Capital. Desde o princípio da República, essa interiorização se tinha constituído em sonho nunca realizado. Tornando-a realidade, Kubitschek pretendia integrar as várias regiões do País entre si e com a Capital [...] Na verdade, a rodovia seria mais exatamente chamada São Paulo-Belém ou o trecho Anápolis-Belém da ligação Sul-Norte (HÉBETTE, MARIN, 2004, p. 36).
\end{abstract}

Esta logística oferecida foi central na expansão de fronteiras econômicas, despertou interesse por matérias-primas, propriedade fundiária e fomentou investimentos em projetos industriais e agroindustriais distintos, tendo como resposta imediata a ampliação da população local. Diante desta assertiva a cidade: "[...] assumiu o papel de elemento de mediação entre as políticas de desenvolvimento pensadas para a região e a ressocialização da população migrante (PEREIRA, 2006, p. 24)".

Dessa forma, não se pode afirmar espontaneidade no processo de urbanização neste caso, já que mesmo no ciclo da borracha, ou mesmo anteriormente, impulsos externos, "orientações" operaram sobre o ambiente local, tendo as paisagens e dinâmicas, sido influenciadas diretamente, forjando orientações particulares. Destarte, Hébette e Marin (2004, p. 42) apontam para a experiência de um processo de colonização dirigida, visto as ações do Estado brasileiro, já que:

\footnotetext{
A distinção entre colonização espontânea e dirigida diz mais respeito, no contexto moderno, aos momentos e à intensidade da interferência do poder público [...] As experiências das rodovias Belém-Brasília e Transamazônica, respectivamente, poderiam servir de ilustração para essa afirmativa.
}

Este processo seguiu ininterrupto nas décadas posteriores (de 1970 e 1980), culminando em conformações que se observa na atualidade e é concebida enquanto ambiente urbano em Belém do Pará. As repercussões se dão diretamente em sua evolução, 
unindo passado e presente na cidade. Conforme Pereira (2006, p. 24) no traçado estadual estas ações perfazem:

[...] um conjunto de transformações sobre a urbanização da região, cujas características, para as décadas de 1970 e 1980, podem ser descritas da seguinte forma: a valorização dos centros localizados às margens das rodovias; a reprodução de pequenos núcleos dispersos - povoados e vilas - vinculados à mobilidade do trabalho; a retratação de núcleos antigos, que ficaram isolados à margem da nova circulação; a imputação de franjas urbanas avançadas [...] os estudos mais recentes indicam novas tendências [...] o reforço da metrópole dispersa ou "metropolização" [...] de um lado, a proliferação de pequenas cidades e o crescimento dinâmico de novos núcleos $[\ldots]$

São estas "franjas urbanas" que são compostas por indivíduos que em sua maior parte migraram do campo para a cidade ou vivem no local a muito tempo, porém anteriormente não visto, nem vivenciado como ambiente urbano. Estes locais se apresentam em grande parte nas ilhas que compõe o município.

O município de Belém do Pará é composto por cerca de 2/3 de área por ilhas, ilhas as quais se compõe por uma diversidade de características naturais. Dentre estas, muitas apresentam estruturas urbanas, algumas lembrando ambientes urbanos, outros rurais. Mesmo diante dessas estrutura, a delimitação territorial extrapola as suas características naturais.

Diante destas estruturas, as Ilhas de Cotijuba e Mosqueiro comportam ambientes urbanos na delimitação política e em muito lembram ambientes rurais. A Ilha de Mosqueiro possui inclusive plano diretor, conforme Silva (2010, p. 40): “A Lei $\mathrm{n}^{\circ}$ 7.684, de janeiro de 1994, dispõe sobre o Plano Diretor e versa como instrumento básico da política de desenvolvimento e da expansão urbana. Este Plano versa sobre a função social das ilhas e sobre a propriedade imobiliária de fins urbanos [...]".

Quanto a Mosqueiro, Silva (2010, p. 41) define da seguinte forma:

É a maior ilha do município, com 21.254,67 ha, possuindo área maior que a continental (17.378,63 ha) de Belém. Comunica-se ao município por ligação rodoviária, construída tendo por base justificativas atreladas ao potencial turístico que a ilha possui. Apesar de sua área física, apresenta baixa densidade populacional, em especial no ambiente rural [...] A população que reside no ambiente urbano é de 26.139 habitantes, em contraste aos 1.757 habitantes residentes no ambiente natural [...] A ilha possui ainda praias em suas faces oeste e norte, com habitações que são ocupadas durante a temporada de veraneio, período em que a população chega a atingir cerca de 250.000 pessoas.

Em relação à ilha de Cotijuba a descrição de Silva (2010, p. 43) é a seguinte:

Geo UERJ - Ano 14, no. 23, v. 1, $1^{\circ}$ semestre de 2012 p. 192-222

ISSN: 1415-7543 E-ISSN: 1981-9021

http://www.e-publicacoes.uerj.br/index.php/geouerj 
Esta ilha apresenta fatos pertencentes à história da cidade de Belém [...] houve em Cotijuba uma escola para reeducação de menores infratores, mais tarde transformada em presídio [...] No passado, Cotijuba destacou-se como um importante centro abastecedor de hortifrutigranjeiros, tendo este quadro se modificado com a alteração do perfil do varejo na cidade e pela dificuldade de colocação de produtos no mercado [...] Existem plantios diversos na ilha [...].

Tão logo, observa-se nestes dois casos, espaços nos quais a urbanidade engloba o seu espaço (mesmo quando não totalmente) e guarda consigo, ambiências rurais, hábitos, cultura e relações interpessoais. Conforme Oliveira (2010, p. 43):

[...] engendrou-se um espaço urbano reduzido a fragmentos articulados, que a todo custo a centralidade imposta pelo poder coercitivo atraiu, normatizou e hierarquizou. Por sua vez, a centralidade que se impôs tentou reduzir as diferenças e produzir um espaço urbano homogêneo. Essa homogeneidade ficou aparente, visto que a cidade é fragmentada, podendo ser identificadas várias cidades dentro das cidades maiores, e cidades as mais diversas nas cidades menores.

Diante desta realidade, observa-se o avanço urbano e a manutenção de estruturas que permanecem (mesmo com alterações) em práticas cotidianas, produtivas e de ocupações. Além disso, mesmo as inserções produtivas modernas carecem de organizações que levem consigo demandas de uma população cada vez maior, com menor demanda de mão-de-obra (em relação à produção como um todo) e que necessita de alimentação. Diante desta perspectiva, o espaço Urbano de Belém do Pará abarca, já há algum tempo práticas vinculadas à produção agrária, logo, se encontra envolvida com o que denomina-se Agricultura Urbana e possui dinâmicas diversificadas que abrangem dinâmicas relacionadas a mesma.

\section{Percursos Investigativos da Pesquisa}

A partir do objetivo acima proposto a abordagem partiu da definição do método de análise dedutivo. Particularmente quanto ao método dedutivo "A premissa maior é uma afirmação universal indiscutivelmente aceita por todos. A premissa menor é um caso particular da premissa maior[...]”(ALMEIDA, 1989, p.17).

Com base nessa premissa, procura-se alcançar os objetivos propostos tendo como fim as realidades locais e como fundamento das análises em questão à abordagem do geral para o particular (da totalidade das atividades e ações para as especificidades), 
das idéias para os fatos (dos ideários para a realidade em sua essência) e das generalizações para a observação in loco do fenômeno estudado (ampliação da escala da análise visando as peculiaridades) em sua manifestação nos espaços focados na presente pesquisa.

A área escolhida para a presente foi o município de Belém do Pará-PA (área de $1.059,402 \mathrm{Km}^{2}$ ) que conta com uma população de 1.393 .399 das quais 1.381 .475 são habitantes urbanos (sendo apenas 11.924 habitantes rurais), o que corresponde a 99,14\% do total da população (IBGE, 2010).

Primeiramente foi feita uma etapa de levantamento de dados, informações e pesquisas anteriormente efetuada no Município, assim como em outros referenciais da temática (agricultura urbana); os mesmos foram coletados junto ao Instituto Brasileiro de Geografia e Estatística-IBGE, Organização das Nações Unidas para a Agricultura e Alimentação-FAO, Ministério do Desenvolvimento Social e Combate à Fome-MDS, e Secretaria de Segurança Alimentar e Nutricional-SESAN. Além destes órgãos, foram consultadas outras fontes acadêmicas como monografias e dissertações juntamente com livros e artigos científicos. Posteriormente foram coletados dados no campo em Belém do Pará através de método qualitativo.

Os instrumentos qualitativos se deram por meio de observação não participativa e entrevistas semi-estruturadas junto a 30 produtores e dois caseiros/jardineiros nos espaços urbanos. A coleta de dados em Belém de Pará se deu nos meses de Novembro e Dezembro de 2011. O conteúdo abordado tanto nos questionários quanto nas entrevistas envolveu abordagem sobre fatos referentes à realidade observada e vivenciada na agricultura urbana do Município, e outras que envolvem opiniões, atitudes e preferências. Neste último caso: "Este conjunto de questões tão heteróclito, têm em comum o fato de tratarem pontos impossíveis de conhecer de outra forma [...] (GHIGLIONE e MATALON, 1997, p.114)”.

Assim, as entrevistas, bem como a observação não participativa procuram

[...] atender principalmente finalidades exploratórias [...] utilizada para o detalhamento de questões e formulação mais precisas dos conceitos relacionados. Em relação a sua estruturação o entrevistador introduz o tema e o entrevistado tem liberdade para discorrer sobre o tema sugerido. É uma forma de poder explorar mais amplamente uma questão. As perguntas são respondidas dentro de uma conversação informal. A interferência do entrevistador deve ser a mínima possível, este deve assumir uma postura de 
ouvinte e apenas em caso de extrema necessidade, ou para evitar o término precoce da entrevista, pode interromper a fala do informante (BONI e QUARESMA, 2005, p. 74).

A aplicação dos instrumentos mistos contou com uma amostragem do tipo nãoprobabilística. Este tipo de amostra consiste em acidental e intencional, onde salienta-se que este método

[...] não pode ser adequadamente especificado. Um pesquisador que quer conhecer a opinião dos bóias-frias sobre um determinado projeto de colonização, poderá utilizar esse método, por exemplo, entrevistando os primeiros 100 bóias-frias que encontrar na saída da cidade. Já o segundo consiste em: [...] selecionar um grupo de elementos considerados típicos, em função das variáveis estudadas [...] O critério da escolha, neste tipo de amostra, é a razão e não o aleatório, mas a razão é fundada nos critérios préestabelecidos. (ALMEIDA, 1989, p. 87, grifo do autor).

A observação, nessa pesquisa, cumpriu papel de conjugar-se a outras técnicas de coleta de dados à medida que:

[...] sob algum aspecto, é imprescindível em qualquer processo de pesquisa científica [...] Genericamente a observação é a base de toda investigação no campo social, podendo ser utilizada em trabalho científico de qualquer nível, desde os mais simples estágios até os mais avançados [...] A observação apresenta muitas nuances em face a sua flexibilidade, pois seu objeto de estudo, bem como o objetivo da pesquisa que o utiliza, determina seu tipo e sua metodologia [...] (RICHARDSON, 1999, p. 259).

O tipo de observação a ser empregada foi a não participante, sendo que:

Nesse tipo de observação o investigador não toma parte nos conhecimentos objeto de estudo como se fosse membro do grupo observado, mas apenas atua como espectador atento. Baseado nos objetivos da pesquisa, e por meio de seu roteiro de observação, ele procura ver e registrar o máximo de ocorrências que interessa ao seu trabalho [...] (RICHARDSON, 1999, p. 260).

Conforme sugerido por Richardson, a observação não participante foi utilizada buscando registrar o máximo de fatos e ocorrências, os quais não poderiam ser obtidos apenas por meio de entrevistas. No geral, tais dados caracterizam-se como elementos não previstos/considerados previamente no momento da elaboração dos instrumentos de pesquisa, dado sobretudo às peculiaridades do fenômeno, bem como dos locais de sua aplicação. 
O delineamento da análise da pesquisa caracterizou-se como analíticodescritivo, de forma que as estratégias de pesquisa traçadas tiveram atuações paralelas ao longo do estudo. $\mathrm{O}$ estudo descritivo possibilitou: “[...] objetivos mais precisos e explícitos em relação aos fatos observados. Descreve mais claramente as características de uma situação ou de um grupo de indivíduos [...] (ALMEIDA, 1989, p. 71)”. O estudo analítico, por sua vez, procurará estabelecer e analisar relações entre as variáveis, baseando-se sobre fatos e tendo como ponto de partida as relações que proporcionarão posteriormente explicações acerca de determinados fenômenos em particular (ALMEIDA, 1989); como por exemplo, a temática da agricultura urbana desenvolvida no espaço urbano.

Por fim, a análise consistiu na tabulação das informações coletadas, a partir da transcrição das entrevistas, fazendo-se uso da análise de conteúdo. “As diversas definições coincidem em que a análise de conteúdo é uma técnica de pesquisa e, como tal, tem determinadas características metodológicas: objetividade, sistematização e inferência (RICHARDSON, 1999, p. 223)"'. Ao encontro desta assertiva:

[...] é preciso estar bem consciente de que, à primeira vista, no caso da análise de entrevista, a questão mais importante parece ser "o quê?". Nesta situação particular, "o quê" fornece, em princípio e desde logo, a possibilidade de responder a todas as outras perguntas. Sabemos "quem" falou e "a quem". O "como" e "para que fim" parecem ser menos bem definidos, mas acabam por ser relativamente claros: o sujeito fala porque nós lhe pedimos e a resposta ao "como?" encontra-se no seu próprio discurso (GHIGLIONE e MATALON, 1997, p. 184).

As categorias de análise cumpriram os requisitos de homogeneidade (por critérios de classificação), exaustividade (alcançar a totalidade do texto), exclusão (elementos pertencentes a apenas uma categoria) e objetividade (RICHARDSON, 1999). Portanto, na análise de conteúdo foi efetuada no intuito de alcançar a objetividade das informações das entrevistas, foram cunhadas categorias de análise, nas quais distinguiram-se assuntos, a fim de registrá-los e codificá-los e sistematizá-los com maior facilidade.

\section{As relações Campo-Cidade e a Agricultura}


O espaço em sua dinâmica, em seus processos formativos, se configuram articulando elementos da natureza, práticas e vivências sociais, forjando assim unidades similares e outras díspares são. Os processos de transformação constituem locais, divisões que se fazem principalmente em torno das atividades produtivas, sendo assim, “[...] formas conteúdos que estão sempre em processo relacional do mesmo movimento: a vida (MONDARDO, 2008, p. 115)".

Tão logo, as divisões dos "mundos" rural e urbano, num país urbano como o Brasil (e não apenas neste) encontra uma série de circunstâncias peculiares e divisões sobre as quais as normativas sobrepujam a organização espacial. Exemplo disso pode ser observado no caso exposto por Wanderley (2009, p. 311): "as pequenas cidades, consideradas urbanas pelo IBGE, conhecem uma experiência urbana, que é, frequentemente, frágil e precária".

Para tanto, a própria concepção de urbano e rural merecem atenção. Nesta perspectiva o que se observa em território nacional demonstra que:

[...] a vigente delimitação de caráter inframunicipal dos territórios urbanos só é adotada por um pequeno punhado de países, como El Salvador, Equador, Guatemala e República Dominicana. Na companhia desses quatro pequenos países, o Brasil considera urbanos os habitantes de qualquer sede municipal, mesmo que tais localidades pertençam a ecossistemas dos menos artificializados (VEIGA, 2003, p. 65).

A compreensão de "urbano" abarcaria em sua demarcação “[...] cidade todas as sedes municipais existentes, independentemente de suas características estruturais e funcionais (VEIGA, 2003, p. 63)”. O autor José Eli da Veiga ainda chama a atenção para o fato de que: "[...] os perímetros urbanos de muitos municípios engolem plantações, pastos e até imensos projetos de irrigação[...] (VEIGA, 2003, p. 57)”. Para este, a delimitação urbana deveria levar em conta aspectos atualmente não observados, pautados em critérios estruturais e funcionais como:

[...] Critérios estruturais são, por exemplo, a localização, o número de habitantes, de eleitores, de moradias, ou, sobretudo, a densidade demográfica. Critério funcional é a existência de serviços indispensáveis à urbe. Exemplo ilustrativo é Portugal, onde a lei determina que uma vila só poderá ser elevada à categoria de cidade se, além de contar com um mínimo de 8 mil eleitores, também oferecer pelo menos metade dos seguintes dez equipamentos: a) hospital com permanência; b) farmácias; c) corporação de bombeiros; d) casa de espetáculos e centro cultural; e) museu e biblioteca; f) instalações de hotelaria; g) estabelecimentos de ensino preparatório e 
secundário; h) estabelecimentos de ensino pré-primário e creches; i) transportes públicos, urbanos e suburbanos; j) parques e jardins públicos (VEIGA, 2005, p. 74).

Concretamente a reflexão acerta das formas e processos existentes no ambiente urbano, bem como suas designações, sua vocação econômica, parece ser um elemento fundamental para a delimitação efetiva do local, como apontam, por exemplo, Lindner e Wandscheer (2010, p. 149-162):

\begin{abstract}
Mesmo com a expansão física de características urbanas no espaço rural, não é possível dizer que este "urbaniza-se", pois mesmo englobando características do modo de vida dito urbano, ele ainda conserva características peculiares à vida e os costumes rurais. [...] os aspectos produtivos e culturais locais diretamente ligados aos hábitos rurais conduzem a uma determinada configuração que se dá não somente na estruturação das festividades locais, mas sim, em todos os hábitos cotidianos.
\end{abstract}

Existem ainda os espaços denominados como rururbanos, na qual,

[...] la acelerada urbanización de la población replantea conceptualizaciones y abordajes del medio rural integrando la dimensión territorial (rururbana) en sus múltiples dinámicas y aspectos (ambientales, políticos, sociales, económicos, etc.) [...] integrando complejos rururbanos de encadenamientos de servicios e insumos relacionados con la producción y el consumo localregional [...] y la necesidad de pasar a un proceso abierto de coordinación económica, social y política entre la multiplicidad de actores e intereses (públicos y privados) que intervienen en los procesos de desarrollo (GORENSTEIN, NAPAL, OLEA, 2007).

Assim, a marca dos espaços rururbanos apresentam-se como uma faixa de transição, mesclando atividades e características muito peculiares, onde os três setores da economia se articulam e conformam o local.

A figura 1 a seguir, apresenta um esforço em apresentar gradativamente paisagens que vão do rural tradicional ao urbano convencional, tendo elencado outras quatro formas de apresentar espaços que se aproximam mais a um ou a outro, porém guardando em suas paisagens porções compostas por formulações de ambos. 


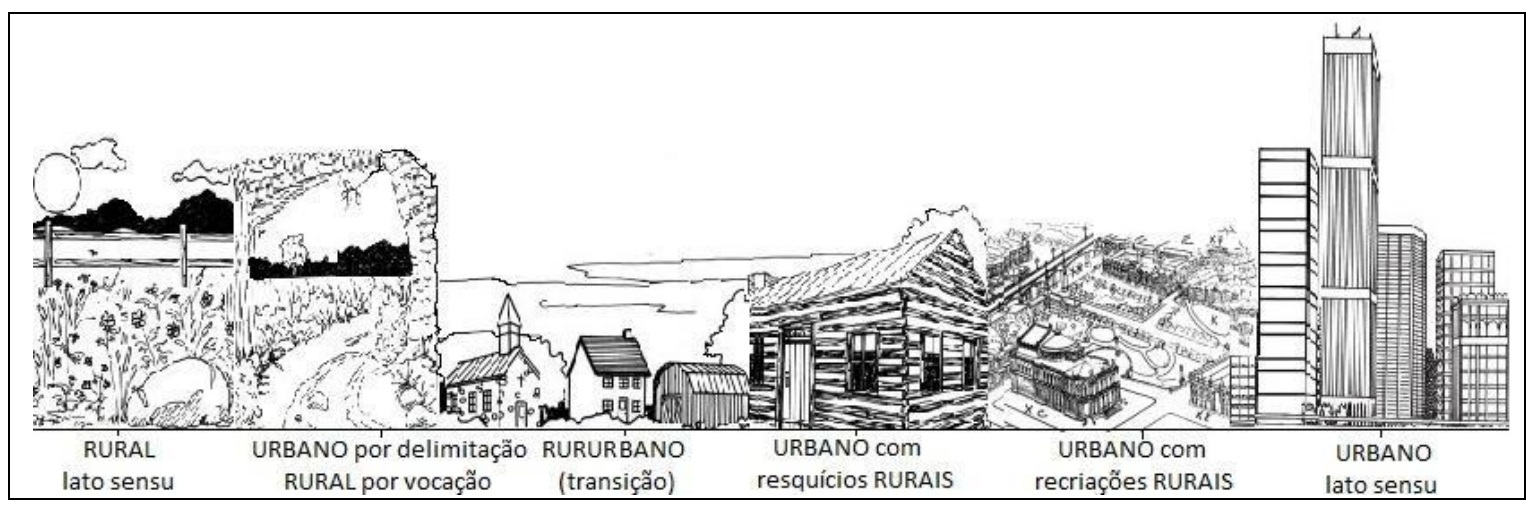

Figura 1: Graduações do Rural ao Urbano e suas interfaces

Fonte das Imagens: EDITORES DO PUBLICATIONS INTERNATIONAL (2012) e OLIVEIRA (2012) apud FREIRE (1911)

Denominações, Organização, Adaptação e Sistematização: WANDSCHEER, E. A. R. (2012)

Inicialmente a figura expressa o rural "latu sensu", locais que expressam o rural em condições específicas de vinculação com a produção e a natureza. Para Abramovay (2009, p. 27): “[...] três aspectos básicos: a relação com a natureza, a importância das áreas não-densamente povoadas e a dependência do sistema urbano".

A situação seguinte na graduação proposta mantêm os parâmetros anteriormente descritos, contudo, apresenta uma diferença, a delimitação políticoterritorial. A seguinte indagação efetuada por Veiga (2005, p. 71) aparece de forma crucial nesta perspectiva: “[...] será que faz algum sentido supor que seja cidade uma sede de município que não tenha sequer lei de zoneamento, plano diretor, coleta de lixo domiciliar, IPTU progressivo, varredura de ruas, manutenção de visas ou esgoto [...]?”

Frente a esta indagação, a diferença dos locais não são de cunho estrutural, mas sim, formais, pois não raro, áreas rurais são elevadas a categoria de cidade instigados por fins especulativos imobiliários ou arrecadações de impostos.

Quando transcorrem mudanças no espaço rural, inicia-se um processo em que pode-se observar uma mescla de práticas, estruturas e organizações atribuídas ao rural, porém com inserções dotadas de características urbanas, principalmente no que toca a infra-estrutura e conexões via acesso a mercados (tanto locais e regionais quanto nacional e internacional). Portanto:

[...] la importancia de las relaciones con el afuera en el proceso constante de construcción de los lugares brinda la posibilidad de descubrir condiciones de "urbanidad" en lugares a los que debería categorizarse como rurales, de acuerdo a la clasificación censal. Esta situación se manifiesta especialmente en aquellas aglomeraciones que por sus condiciones de localización favorables han sido objeto del repoblamiento [...] (BARROS, 1999).

Geo UERJ - Ano 14, no. 23, v. 1, $1^{\circ}$ semestre de 2012 p. 192-222

ISSN: 1415-7543 E-ISSN: 1981-9021

http://www.e-publicacoes.uerj.br/index.php/geouerj 
Para alguns autores relacionados à lógica Lefebrviana, este processo se daria em função do processo pelo qual os lugares estariam passando, rumando para uma conformação urbana, seria uma metamorfose natural que levaria(á) a uma sociedade urbana. Estas abordagens são constantemente alvo de debates, questionamentos e acréscimos de ideias e adendos, porém o que parece inegável é que entre a relação ruralurbano, a subordinação do primeiro parece o caminho talhado rumo à consolidação de uma série de demandas do segundo. Este processo é na maioria das vezes apresentado como "sociedade urbana" conforme o próprio Lefebvre (1999, p. 15-16) aponta:

[...] Estas palavras designam, portanto, a sociedade constituída por esse processo que domina e absorve a produção agrícola. Essa sociedade urbana só pode ser concebida ao final de um processo no curso do qual explodem as antigas formas urbanas, herdadas de transformações descontínuas[...] Para denominar a sociedade pós-industrial, ou seja, aquela que nasce da industrialização e a sucede [...] a sociedade urbana.

A partir desta conceituação, mesmo diante de questionamentos diversos, podese observar que nesses espaços rururbanos, de forma mais marcante se esboçam:

[...] formas diferenciadas de inserção no mercado e de acesso à infra-estrutura viabilizada pelo Estado, o que determina também, a viabilidade econômica da produção agrária, o acesso a terra, a territorialidade dos lugares quanto a sua possibilidade estabelecer relações com outros lugares [...] em outras palavras, diferente oportunidades de inserção no mundo globalizado (FONTOURA, 2009, p. 277).

O processo seguinte, já constitui o espaço urbano propriamente constituído, que além da delimitação territorial, pouco guarda de aspectos rurais em organizações e estruturações locais.

Esta abordagem que envolve características locais, enaltece a particularidade de atividades que se mantêm enquanto resquícios e manutenções que extrapolam o aspecto produtivo-econômico, pois envolvem características sociais e culturais de relação com o meio e a forma de conceber a produção alimentícia.

A etapa seguinte já constitui um urbano ainda mais avançado, mas que agora apresenta necessidades no quesito ambiental e a partir desse passa a visualizar diferentemente algumas questões como observa Wanderley (2009, p. 46): “[...] as relações entre o "atrasado" e o "moderno" se expressam, não enquanto polos opostos, 
ou como termos de uma evolução, mas como um processo de reprodução recíproca, o 'atrasado' qualificando o 'moderno'”.

Existem ainda, "recriações" rurais no âmbito urbano que se concretizam em iniciativas que procuram abarcar demandas recorrentes nos limites citadinos. Estes são:

[...] a preservação e recuperação dos parques urbanos tal como espaços livres [...] seja esta, individual ou coletiva, pois só assim conseguimos entender o seu processo, a sua forma, a sua função e a sua estrutura como elemento integrante do espaço urbano através dos tempos, pois os parques urbanos precisam ser percebidos como um lugar para a cidade que integra a paisagem (BOVO e AMORIM, 2011, p. 347-348).

Por fim, existe a situação do urbano "latu sensu", espaço esse ao qual não se observa a presença do rural e de atividades agrárias, pois estas dificilmente se encontram presentes. Nestes espaços a relação espaço-tempo torna-se crucial, ainda mais quando se tratando de espaços localizados em áreas mais populosas e com maior volume de empresas e intensas em serviços, tais como municípios e regiões metropolitanas.

\section{Agricultura Urbana (AU)}

Partindo das interações compreendidas e apontadas por muitos autores entre o urbano e o rural, bem como a convivência mútua de realizações, iniciativas e inovações (ainda que com aplicações diferenciadas), observam-se espaços denominados por muitos autores como híbridos. Há que se considerar que cidades de menor porte tendem a se estruturarem produtivamente mais em torno de atividades agrícolas, porém não se pode ignorar a possibilidade do urbano sediar ambientes mais vinculados a natureza.

Ainda que "[...] a diversidade de contribuições direcionadas ao estudo da relação campo-cidade, rural-urbano, não se esgotou e tampouco há um consenso entre os pesquisadores sobre o tema (MONDARDO, 2008, p. 117)", o que se têm é uma:

[...] relação recíproca. Além disso, o campo não é sinônimo de rural e, tampouco a cidade abarca apenas o urbano. $\mathrm{O}$ rural e o urbano expressam o modo de vida e os valores, enquanto o campo e a cidade correspondem à materialização desses modos de vida. Portanto, os valores urbanos estão presentes no campo, assim como também encontramos os valores rurais na cidade (MONDARDO, 2008, p. 118). 
Considerando uma manifestação dos “enlaces" entre urbano e rural, o elemento central que anteriormente os diferia, atualmente também apreendido enquanto forma de aproximação/inserção, torna-se necessário avançar nas definições que norteiam a temática da AU. A Organização das Nações Unidas para a Agricultura e a Alimentação (FAO) apresenta da seguinte forma:

A produção e/ou transformação de forma inócua de produtos agrícolas (hortaliças, frutas, plantas medicinais, plantas ornamentais, espécies florestais etc.) e pecuários [...] nas áreas intra e periurbanas das cidades, para autoconsumo ou comercialização, aproveitando recursos, insumos e serviços urbanos (solo, água, resíduos, mão de obra, etc.) (FAO, 2009).

Como um dos maiores debates, costuma estar presente à qualidade de produção dos alimentos, oferecendo assim, alternativa concreta a populações de baixa renda e, também é marcada pelos potenciais nutricionais que oferece. "Dentro de este contexto, se justifica la práctica de la agricultura urbana (AU) como uma actividad que promueve la producción de alimentos frescos, saludables y a bajo costo [...] (IZQUIERDO; GRANADOS, 2009, p.42)".

A AU pode ainda estender-se como ganhos de capital, mas esta característica não costuma ser tão enfatizada, pois na maioria das vezes é:

[...] realizada em pequenas áreas dentro de uma cidade, ou no seu entorno (peri-urbana) [...] Difere da agricultura tradicional (rural) em vários aspectos: [...] a área disponível para o cultivo é muito restrita na agricultura urbana. [...] há escassez de conhecimentos técnicos por parte dos agentes/produtores diretamente envolvidos; frequentemente não há possibilidade de dedicação exclusiva à atividade; a atividade destina-se, normalmente, para utilização ou consumo próprio; há grande diversidade de cultivos; e a finalidade da atividade é distinta [...] (ROESE, 2009, p. 1).

Elemento importante na reflexão acerca da AU compete à denominação efetuada, pois existem variações em função de matizes teóricas diferenciadas, assim como em função da abordagem e tendências dos autores, vide quadro 1.

\begin{tabular}{|c|l|}
\hline $\begin{array}{c}\text { FORMAS DE } \\
\text { DENOMINAÇÃO }\end{array}$ & \multicolumn{1}{c|}{ TERMINOLOGIA } \\
\hline Agricultura Urbana & $\begin{array}{l}\text { Conceito que abarca a produção agrárias nos limites do espaço urbano, de caráter e dinâmica } \\
\text { multidimensional, podendo envolver produção, transformação. Distingue-se das atividades } \\
\text { urbanas comuns, mas abarca diversidades de uma série de outras atuações citadinas, vincula } \\
\text { potenciais de comercialização e articulação entre locais e localidades próximas. Porém, } \\
\text { conserva consigo (transformando, adaptando e (re)criando o processo produtivo) a } \\
\text { centralidade no alimento, este mais comum ao campo, porém não ausente no urbano, ainda } \\
\text { que com maiores dificuldades no tocante a área. Pode ser desenvolvido em caráter }\end{array}$ \\
\hline
\end{tabular}

Geo UERJ - Ano 14, nº. 23, v. 1, $1^{\circ}$ semestre de 2012 p. 192-222

ISSN: 1415-7543 E-ISSN: 1981-9021

http://www.e-publicacoes.uerj.br/index.php/geouerj 


\begin{tabular}{|c|c|}
\hline & $\begin{array}{l}\text { individual, familiar ou comunitário e não costuma empregar mão de obra remunerada, de } \\
\text { forma que, quando o faz se dá em pequenas quantidades. Além disso, costuma utilizar pouco } \\
\text { maquinário e tecnologia em sua produção, sendo a mesma voltada a demandas do mercado } \\
\text { ou autoconsumo, neste último caso, sendo empregada comumente em comunidades pobres. } \\
\text { Costuma estar relacionada a temáticas como segurança alimentar, sustentabilidade e } \\
\text { planejamento, estando articulada com questões da gestão e planejamento do espaço urbano. }\end{array}$ \\
\hline $\begin{array}{l}\text { Agricultura Urbana } \\
\text { e Periurbana }\end{array}$ & $\begin{array}{l}\text { Termo empregado com a mesma finalidade do anterior, porém incorpora o termo } \\
\text { "Periurbana" ao final. Assim como o termo anterior, contempla a produção agrárias nas } \\
\text { limitações urbanas, porém, distingue áreas dentro do espaço urbano, e, sobretudo em cidades } \\
\text { maiores, induzindo a conclusões que perfazem destinos mais periféricos aos locais com } \\
\text { proeminência de maiores produções. Para aqueles que incorporam análises com pequenas } \\
\text { Hortas parece haver maior significância tal substantivação, do contrário muito pouco altera o } \\
\text { sentido da denominação anterior. É o termo mais empregado em projetos e ações de políticas } \\
\text { públicas. }\end{array}$ \\
\hline $\begin{array}{l}\text { Urbanidades no } \\
\text { Rural ou } \\
\text { Ruralidades no } \\
\text { Urbano }\end{array}$ & $\begin{array}{l}\text { Este termo costuma estar intimamente ligado a discussões acerca das relações campo-cidade, } \\
\text { bem como as inserções do urbano no rural e vice-versa. Em torno de tal definição, a } \\
\text { atividade agrárias na(s) cidade(s), seus impactos e implicações acabam tornando-se fatores } \\
\text { no entorno da problemática central, mesmo quando tratada com relevância, não costuma } \\
\text { definir-se como abordagem fundamental do(s) autor(es). }\end{array}$ \\
\hline $\begin{array}{l}\text { Hortas } \\
\text { Comunitárias }\end{array}$ & $\begin{array}{l}\text { A atividade costuma dirigir-se a produtores de baixa renda, atuando de forma a buscar em } \\
\text { espaços limitados, melhorias alimentares que se materializam praticamente em alimentos, } \\
\text { salvo algumas exceções. Tal iniciativa possibilita maior possibilidade de sucesso, uma vez } \\
\text { que agrupados, os produtores passam a ter mais (e melhor) acesso a insumos, créditos e } \\
\text { outros serviços de assessoramento e capacitação que podem auxiliá-los. Contudo, } \\
\text { costumeiramente acabam por organizarem-se em grupos de forma a articular necessidades } \\
\text { e objetivos em comum, e não puramente a articulação em prol de benefícios conjuntos, } \\
\text { relação advinda de sua(s) articulação(ões). Mesmo diante de tal realidade, a utilização do } \\
\text { termo "Horta" acaba por fazer-se diante de cenários nas quais a produção apresenta } \\
\text { limitações, sobretudo de área, permanecendo muito mais por quesitos voltados a } \\
\text { deficiências locais do que pela ênfase em potenciais futuros, portanto, um tanto quanto } \\
\text { disperso de abordagens que tenham em foco questões que norteiam a questão econômica. }\end{array}$ \\
\hline Hortas & Denomina o fenômeno idêntico ao anterior, porém sem o caráter coletivo. \\
\hline $\begin{array}{l}\text { Urbano Agrícola ou } \\
\text { Agropecuário }\end{array}$ & $\begin{array}{l}\text { Utilizado para toda e qualquer produção agrícola ou agrárias, costumando compreender a } \\
\text { produção e sua implicação na esfera em que se encontra situada. Portanto, aparece de forma } \\
\text { mais sucinta em termos de abrangência da totalidade. }\end{array}$ \\
\hline $\begin{array}{l}\text { Rural Agrícola no } \\
\text { Urbano }\end{array}$ & $\begin{array}{l}\text { Abordagem envolvendo características socioeconômicas, ambientais e por vezes culturais, } \\
\text { onde permanecem práticas anteriores, porém, atualmente situadas em espaços urbanos, logo, }\end{array}$ \\
\hline
\end{tabular}

Quadro 1. Denominações atribuídas a terminologia Agricultura Urbana

Elaboração e Sistematização: WANDSCHEER, E. A. R. ${ }^{5}$

Conforme exposição anterior, as diferentes denominações utilizadas para as práticas que constituem a produção agrária em espaços urbanos demonstram diversidade e necessidade de enfoque que diretamente refletem percursos e metas dos diferentes autores, bem como as necessidades de sua pesquisa, demonstrando a necessidade de ampliação do leque de análise dada às circunstâncias e peculiares que envolveram

\footnotetext{
${ }^{5}$ A redação do quadro levou em conta a abordagem de distintas denominações existentes em obras referentes à temática Agricultura Urbana, denominações encontradas em: Arruda e Arraes (2007), FAO (2009), Ferreira e Castilho (2007), Kozenieski (2010), Rua (2006), Santandreu e Lovo (2007) e Santos e Silva (2010) e Madaleno (2002). Ambos substantivos referentes ao fenômeno enfocado, a Agricultura Urbana.
}

Geo UERJ - Ano 14, nº. 23, v. 1, $1^{\circ}$ semestre de 2012 p. 192-222

ISSN: 1415-7543 E-ISSN: 1981-9021

http://www.e-publicacoes.uerj.br/index.php/geouerj 
características da composição da Agricultura Urbana. Conforme FAO (2009), a estruturação de sistemas de produção mais frequente, são:

[...] embora em muitos lugares eles possam estar integrados ou adaptados, sempre dependendo das condições locais: 1) Microagricultura no quintal da moradia ou perto dela, 2) Horticultura comunal/comunitária, 3) Agricultura urbana institucional, 4) Horticultura (semi)comercial de pequena escala, 5) Criação de animais e produção aquática (semi)comercial de pequena escala, 6) Granjas multifuncionais e 7) Produção especializada de agricultura e silvicultura urbana.

Mais extenso como definição, o substantivo Agricultura Urbana e Periurbana efetua uma abordagem que trás consigo uma divisão entre as atividades produtivas mais centralizadas na cidade e as áreas mais periféricas. O seu emprego principalmente em municípios maiores e regiões metropolitanas costuma ocorrer, principalmente em projetos de cunho político, planejamento e definições. A adjetivação "periurbana" em muitos casos não se expressa de forma necessária, pois espaços centrais em grandes cidades quando abarcam esta atividade se concretizam como pequenos espaços tais como pequenas hortas ou mesmo agricultura vertical.

Quanto à abordagem de hortas, existe a evidência de um enfoque analítico mais específico, costuma variar um pouco quando efetuado de forma individual e coletiva, sendo neste último substantivo direcionado a produtores de baixa renda ou atividades educativas como no caso das escolas, dificilmente é efetuado em caráter econômico. A utilização da terminologia Horta devido à realidade de limitações espaciais, apresentam um caráter específico de pequena produção, complementariedade de alimentos e escassa renda, não se tornando tão representativo em trabalhos voltados a esfera econômica. A FAO (2009) expõe o assunto seguinte em torno da atividade como:

Por exemplo, uma comunidade de produtores urbanos se encontra assentada em uma zona cujo uso previsto do solo não é o agrícola. Sua prática de produção de hortaliças para autoconsumo e comercialização tem sido desenvolvida por muitos anos, porém os produtores agora começaram a se ver submetidos por pressões do setor imobiliário, que pretende construir nas áreas de cultivo.

Existe ainda a possibilidade de o fenômeno ser tratado como Urbano Agrícola, Agropecuário ou Rural Agrícola no Urbano (ou área metropolitana). As produções nesse sentido encontram-se, não raro, em espaços rururbanos, tendo suas abordagens 
um enfoque conceitual que não faz menção a Agricultura Urbana. Cabendo, portanto, a opção de denominação da produção agrária em espaço urbano e as relações advindas da mesma como modos de vida e/ou outros particularismos ao(s) autor(es) das obras.

Por fim, o termo Agricultura Urbana parece ser mais adequado a abordagens socioeconômicas, pois expressa menor direcionamento a uma forma específica de desenvolver a atividade produtiva agrícola, expressando a dinâmica multidimensional. Conforme já apresentado, pode envolver produção e transformação em caráter individual, familiar ou comunitário, apresenta raras situações de emprego de mão de obra remunerada, pouco maquinário e tecnologia, além de produções mais sustentáveis. Cabe salientar que a mesma relaciona-se com temáticas como segurança alimentar, sustentabilidade e planejamento.

\section{As Atividades Agrárias na Dinâmica do Espaço Urbano de Belém do Pará-PA}

As práticas de Agricultura Urbana, conforme pode-se visualizar nos conceitos anteriormente apresentados, diferem-se socioeconomicamente, logo, oferecem ocupações, carecem de investimentos e benefícios alimentares ou renda em variadas situações. Nesse sentido, os objetivos são fundamentais para concretizar a forma como a AU se materializa, sendo atividade que envolva a busca por benefícios alimentares ou financeiros, ou então benefícios ambientais e paisagísticos.

Os custos com práticas que voltam-se a benefícios ambientais e paisagísticos são em sua maioria efetuadas pelo poder público, como nos casos de reservas ou parques nas cidades, são custosos e costumam ter seus custos arcados pelo poder público, pois

[...] a criação e manutenção de parques urbanos contribuem para a amenização dos problemas [...] pois as áreas verdes são importantes para a obtenção de uma boa qualidade de vida no ambiente urbano, além do seu valor ecológico, estético e humanístico, ampliando a representação do lugar e da natureza na cidade (BOVO, AMORIM, 2011, p. 323-349).

Existem também situações de condomínios e espaços de prédios onde os moradores possuem melhores condições financeiras, podendo assim, efetuar investimentos para manter uma área que ofereça benefícios paisagísticos e redução da temperatura, por exemplo.

Geo UERJ - Ano 14, no. 23, v. 1, $1^{\circ}$ semestre de 2012 p. 192-222

ISSN: 1415-7543 E-ISSN: 1981-9021

http://www.e-publicacoes.uerj.br/index.php/geouerj 
Já quando os focos são benefícios alimentares ou financeiros, existe a necessidade de a área oferecer benefícios socioeconômicos, variando as especializações, o emprego de mão de obra, e a vinculação ao mercado. Pode-se observar na figura 2 a relação entre produção e o benefício socioeconômico.

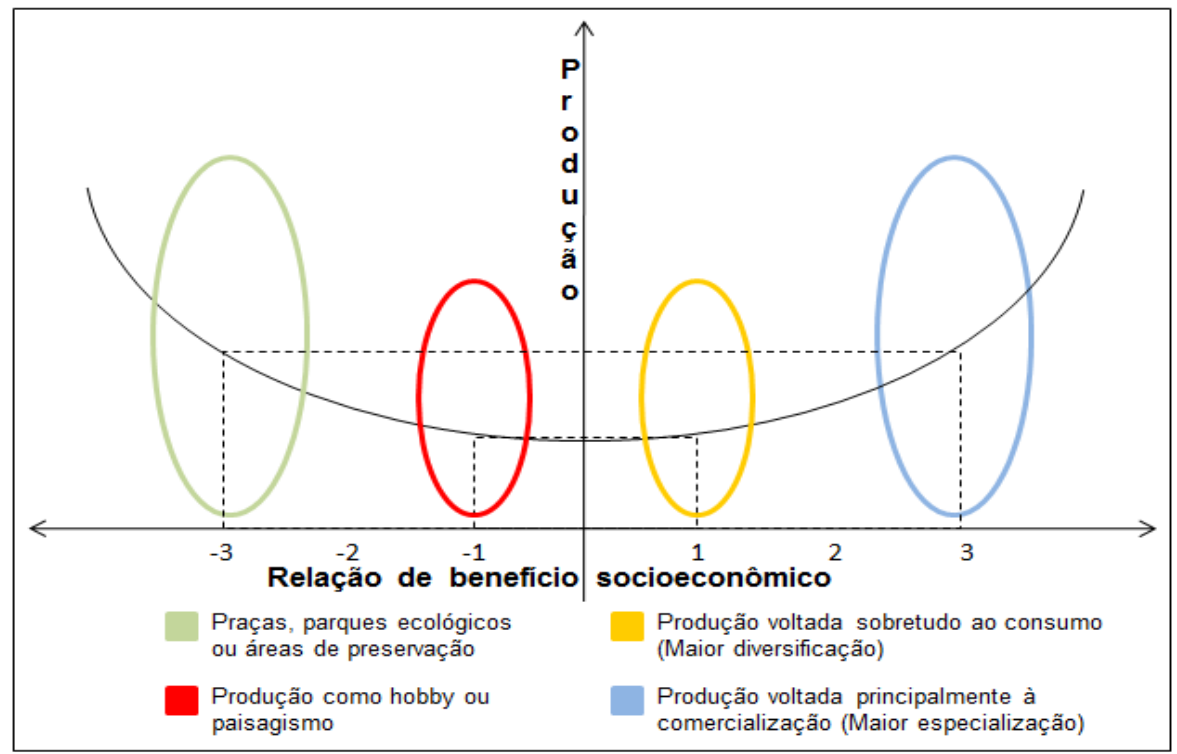

Figura 2: Gráfico da relação produção e benefício socioeconômico Fonte: Trabalho de campo (2011).

Quando situado negativamente no gráfico, os custos se elevam e os benefícios variam entre questões ecológicas, cenário físico ou mesmo lazer. No caso de pequenos custos estão às atividades paisagísticas ou atividades de lazer, sendo originados por insumos e/ou a contratação de mão de obra como caseiros e jardineiros, conforme diz entrevistado na porção central de Belém do Pará:

\footnotetext{
O que os moradores querem é ter um local bonito que agrade os moradores que geralmente passam pelo local e volte e meia mandam as crianças irem pra lá brincar, porque lá eles tem segurança e podem cuidar deles [...] quase nunca comem as frutas ou os temperos da horta [...] é mais pro pessoal olhar... como dizem: é um lugar pra ficar e colocar as crianças mesmo, principalmente nesses calor que faz por aqui (CASEIRO 1).
}

Os custos aumentam à medida que há a necessidade de uma área maior e mais cultivos, e em termos de alimentação ou renda não há retornos, ou quando existentes são muito esparsos. Assim, torna-se necessário contratações como seguranças para cuidarem do local e jardineiros para manutenção. Em ambas as situações, são questões voltadas para melhorar os ambientes urbanos e/ou oferecer espaços de lazer e distração para a população.

Geo UERJ - Ano 14, nº. 23, v. 1, $1^{\circ}$ semestre de 2012 p. 192-222

ISSN: 1415-7543 E-ISSN: 1981-9021

http://www.e-publicacoes.uerj.br/index.php/geouerj 
Em se tratando de questões socioeconômicas, verificou-se duas situações, onde o tamanho da produção é decisivo para elevar custos e geralmente área e ocupações. Os elementos centrais desta relação produção e gastos se dão de acordo com as finalidades da produção, pois quanto mais vinculadas ao mercado, maior é o grau de especialização e menor diversificação dos cultivos.

Estes casos de cultivos mais especializados vinculam-se a iniciativas de agrovilas e assentamentos urbanos. Havendo maior direcionamento ao mercado costuma-se verificar a demanda por produto(s) orgânico ou então produto que sirva de matéria prima a um determinado produto industrial conforme observado na ilha de Cotijuba, fornecedora da Priprioca para uma multinacional do ramo de perfumaria e cosméticos.

As produções costumam se centrar em produtos típicos/culturais dos indivíduos, apenas quando da inserção de produção especializada voltada a indústrias de maior porte, neste caso observa-se a desistência de cultivos tradicionais como espécies frutíferas, temperos e hortas em que plantava-se verduras e e algumas. Tal assertiva pode ser apresentada através dos produtos lembrados por mais de 1/4 dos atores envolvidos indagados na pesquisa, são eles: Açaí (45,2\%), Macaxera (41,9\%), Cupuaçu $(35,5 \%)$ e Maxixe $(25,8 \%)$ (Figura 3$)$.

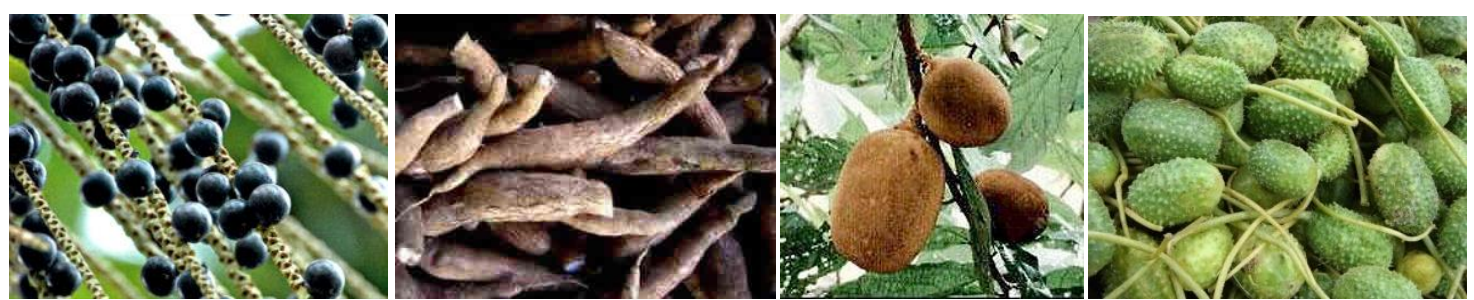

Figura 3: Produtos típicos/culturais produzidos pelos agricultores urbanos (pela ordem: Açaí, Macaxera, Cupuaçu e Maxixe)

Fonte das Imagens: PLANTAS MEDICINAIS \& FITOTERAPIA (2012); PORTAL SÃO FRANCISCO (2012); ARARA (2012); FOIE GRÁS COM DENDÊ (2012)

Org.: WANDSCHEER, E. A. R.

Muito embora tenham sido estes quatro produtos que se destacaram entre os mais lembrados, outros produtos são relevantes no contexto do Município, conforme pode-se observar no caso do Carirú, Côco e O Cheiro Verde. Diante desta perspectiva, a agroindústria parece ser uma possibilidade latente e promissora, em que conste a perspectiva de pequenas unidades, em escalas não muito amplas, pois a mão de obra 
local não é abundante, as áreas têm limitações e a expansão de estabelecimentos poderia comprometer a sustentabilidade produtiva e ambiental dos espaços.

Em que pese a questão da agricultura urbana partir da premissa do autoconsumo, focando as possibilidades para a produção do núcleo familiar, observa-se em diversos locais, sobretudo em áreas de maior extensão (muito embora grande parte em Belém do Pará ocorra como área de preservação), não apenas a possibilidade como a necessidade da obtenção de maior número de mercados, bem como que os mesmos sejam mais perenes e rentáveis, podendo manter características de proximidade (atualmente decorrente da venda direta ao consumidor, comumente turista que perpassa pelas proximidades).

Assim, considera-se a agroindústria como elemento de relevância e potencial não apenas à agregação de valor ao produto, mas também como elemento de inserção de indivíduos à prática agrícola. Ressalta-se que 63,3\% dos entrevistados com filhos informou que os mesmos já não se encontravam mais na propriedade, ou então, pretendiam abandoná-la totalmente ou tê-la apenas como local de moradia. Portanto, esta mudança deu-se a partir do viés de transformação da ideia de pluriatividade externa (como trabalhos de diarista na construção civil, mercados, restaurantes ou serviços domésticos) a atividades que envolveriam uma lógica voltada ao âmbito da propriedade e da produção local. Esta realidade poderia tornar viável economicamente a comercialização de uma série de produtos agrícolas momentaneamente não comercializados, além de ampliar a rentabilidade daqueles atualmente revendidos.

[...] as características da pluriatividade variam de acordo com o indivíduomembro que a exerce, pois tal processo social acarreta efeitos distintos sobre o grupo doméstico e sobre a unidade produtiva [...] variáveis exógenas à unidade familiar, como no mercado de trabalho e a infra-estrutura disponível, entre outros, são fatores determinantes da evolução e tendências de tais fenômenos (SCHNEIDER, 2003, 14).

Juntamente com a agroindústria, a demanda por produtos orgânicos também se constitui num aspecto relevante em termos de mercado para a produção agrícola da maior parte das grandes cidades brasileiras, já que representa oportunidades em particular que valoriza o produto cultivado. Porém nas ilhas de Cotijuba e Mosqueiro, mesmo sendo uma prática que vai ao encontro de características peculiares à produção 
orgânica, observou-se no que apesar de produto diferenciado, o município de Belém do Pará não ocorre à valorização desses produtos.

Nos hábitos se observa a realidade decorrente do fato dos consumidores locais ainda não terem visualizado de forma massiva a presença de produtos convencionalmente produzidos, assim, os mesmos não são uma presença marcante. Aspecto convergente a esta realidade se refere à desinformação que culmina em pouca valorização do consumidor em relação aos produtos que lhes são ofertados. Um exemplo de tal realidade pode ser observado no Lote Agroecológico de Produção Orgânica (LAPO), situado na Agrovila da comunidade Mártires de Abreu (Figura 7), onde toda a sua produção é pautada em princípios agroecológicos.
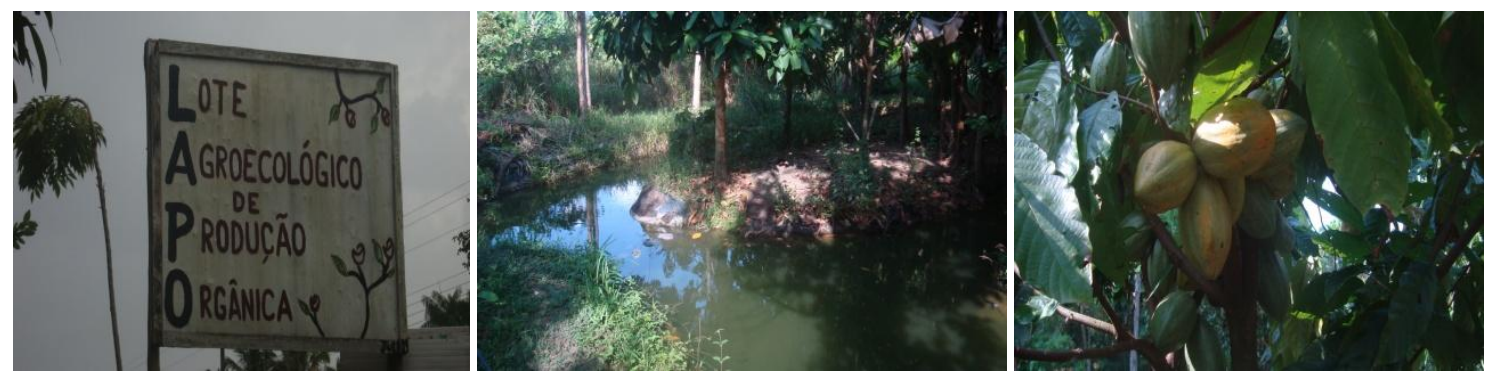

Figura 4: Lote Agroecológico de Produção Orgânica (LAPO)

Fonte: Trabalho de Campo (2011)

Assim, o fato é que estes produtos merecem maior atenção por parte dos agentes públicos, privados (envolvidos na comercialização), bem como dos atores locais envolvidos, pois a partir de tal realidade poder-se-á valorizar produtos que respeitam preceitos ecológicos e não utilizam adubos nem insumos químicos.

A centralidade da produção orbita em torno de práticas agrícolas, uma vez que a pecuária mesmo se fazendo presente e pertencente à práticas agrárias em espaços urbanos, não visualiza maior expressão entre aquelas praticadas. Logo, quando existente, a salvo em casos de piscicultura e avicultura estabelecidos, a prática contempla apenas uma ou duas unidades e não se constitui em produto relevante, tanto que não chega a $1 / 3$ da amostra os indivíduos que citaram a mesma quando questionados.

Quando arguidos acerca desta realidade, as exposições figuraram em torno da dificuldade de sua manutenção, pois a mesma necessidade de insumos para a manutenção dos animais, rentabilidade não compensatória diante da exigência de

Geo UERJ - Ano 14, no. 23, v. 1, $1^{\circ}$ semestre de 2012 p. 192-222

ISSN: 1415-7543 E-ISSN: 1981-9021

http://www.e-publicacoes.uerj.br/index.php/geouerj 
ocupação integral (e existe dificuldade de mão-de-obra nas famílias), além da área, problemática peculiar à agricultura urbana. Conforme o entrevistado:

Para ter algum animal na nossa propriedade precisaríamos de muito mais espaço, teríamos mais trabalho e os lucros não compensariam. Então pra que ter? As vezes temos uma ou duas galinhas no terreno, mas não é permanente e nem queremos que seja, acontece apenas quando alguém nos presenteia. Outros animais nem teremos, pois não temos como tratar (PRODUTOR 26).

A atividade extrativa se concretiza como prática mais efetiva e presente na maior parte dos produtores, estando em mais de $96 \%$ das unidades produtivas visitadas e corresponde a $100 \%$ dos casos quando em se tratando (ao menos) de parte do autoconsumo.

Uma problemática relevante que os indivíduos têm de conviver diariamente se refere ao transporte, em se tratando de comunidades de baixo poder aquisitivo e, sobremaneira quando se refere a ambientes insulares, o transporte marítimo se constitui na única opção para a maior parte destes espaços. Dessa forma, os alimentos mais perecíveis acabam tendo perdas consideráveis, além da qualidade visual, em virtude das altas temperaturas existentes em Belém do Pará, os mesmos não chegam "vistosos" aos mercados ao qual se destinam, ou então, carecem de "intermediários", o que acarreta custos ao produto e, menor margem de lucro do produtor e logo, maiores custos aos consumidores finais. Conforme Santos (2007) a problemática dos transportes e sua alocação em áreas de menor disponibilidade de capital se expressa diferenciadamente, sendo:

\begin{abstract}
As zonas de produção de forte intensidade de capital distorcem a seu favor a utilização dos meios de transporte. Elas podem pagar mais, por unidade de tempo, distância, volume e peso. Se há coincidência de período de comercialização de produtos de diferentes valores mercantis, os mais caros têm prioridade, com perdas tanto maiores para os outros, uma vez que o estoque de veículos de transporte é sempre nitidamente inferior às necessidades globais e que o próprio transporte não é uma mercadoria armazenável. A obrigação de passar por intermediárias cada dia mais numerosas e exigentes acarreta para os usuários, que atualmente vêm de todos os setores produtivos, uma necessidade ampliada de capital circulante (SANTOS, 2007, p. 144).
\end{abstract}

Cabe, porém, um adendo quanto à questão da ilha de Mosqueiro, pois nesta, já existe ligação rodoviária através da ponte existente, possibilitando assim, interligação e 
acessos a mercados. A curiosidade, neste caso, fica a cargo da localização do mercado consumidor, pois o mesmo se estrutura localmente em função dos visitantes que chegam à ilha procurando as praias locais.

Ainda na esfera da problemática do transporte cabe salientar que se constituem em empecilho dois aspectos, são eles: disponibilidade - existe pouco espaço para acomodar produtos e as demandas são elevadas. Assim, o custo se eleva e na maior parte das vezes inviabiliza a produção; e o tempo de durabilidade do produto - os produtos são em sua maior parte perecíveis em um curto período de tempo e a disponibilidade de horários de transporte são restritos.

Pode-se afirmar que essa realidade encontrada no presente trabalho vai ao encontro da afirmação de Madaleno (2002, p. 170), pois em Belém do Pará:

[...] o espaço tem, no geral um valor de uso e não de posse; finalmente, esparciam-se as explorações agrícolas pela periferia em lotes quer individualizados como na ilha de Cotijuba, quer comunitários como no Mosqueiro ou Outeiro, de muito maiores dimensões, normalmente superiores ao hectare $[\ldots]$.

Por fim, cabe um adendo ao que representam as áreas verdes em espaços urbanos, sobretudo em capitais que agregam um grande número de moradores, amenizando temperaturas e oferecendo melhorias ambientais, ou ainda servindo de refúgio ou espaços de lazer à visitação (tanto de habitantes locais como de turistas), o que constitui outro potencial já explorado, mas que ainda tem muito a oferecer em termos de potencialidade socioeconômica.

\section{Considerações Finais}

As práticas agrárias se manifestam em Belém do Pará tanto no espaço rural quanto em seus limites urbanos. Em termos de agricultura urbana, observam-se espaços cultivados tanto no centro quanto na periferia do território urbano, de forma que quando observado nos espaços centrais, o mesmo se dá em pequenos cultivos, ao passo que quando externamente a este, em grande parte os cultivos adquirem maiores proporções e, não raro, são feitos de forma a visualizar mercados para os seus produtos. 
São diversas as situações observadas nos cultivos, variando em função do tamanho da área e do foco produtivo, mantendo sempre alguma preocupação com o autoconsumo. Em muitos casos se volta para nichos de mercado, tal qual o observado em Cotijuba, que vincula a produção e sua dinâmica organizacional do espaço a uma multinacional produtora de perfumaria e cosméticos.

A maior parte dos produtores observados apresenta autonomia em sua produção, ainda que organizados em distribuição ou comercialização, com exceção do caso da produção destinada a multinacional anteriormente citada. Também foram assinalados como principais produtos elaborados pelos agricultores urbanos, aqueles relacionados a peculiaridades tradicionais, assim como raramente utilizam produtos químicos e contam com escassos ou mesmo nenhum maquinário. Além disso, a mão de obra empregada também é pouca, sendo raros os casos que toda a família se ocupa na atividade.

Raramente a pecuária é visualizada nas propriedades e quando presente, pois tratam-se de situações são muito acanhados (uma ou duas unidades de pequenos animais). Parte desta realidade pode ser respondida pela problemática do transporte, esta enfrentada tanto em termos qualitativos (espaços e acondicionamento), quanto em realidades quantitativas, em virtude de escassos transportes.

Ao final destaca-se que as produções observadas são muito importantes para uma parcela da população. Mesmo quando não visualizada como componente de renda, pode-se auferir que a mesma contribui para a sustentação de indivíduos, de famílias. Realidade esta de grande relevância, sobretudo no contexto recente, onde observa-se um crescimento populacional em âmbito mundial, com 7 bilhões de pessoas no mundo e um país com mais de 190 milhões de pessoas.

\section{REFERÊNCIAS}

ABRAMOVAY, R. O futuro das regiões rurais. 2. ed. Porto Alegre: Ed. da UFRGS, 2009.

ALMEIDA, J. A. Pesquisa em extensão rural. Um manual de metodologia. Brasília: Associação Brasileira de Educação Agrícola Superior, 1989. 
ARARA. Cupuaçu. Disponível em: <http://www.arara.fr/BBCUPUACU.html>. Acesso em 26 jan. 2012.

ARRUDA, J. ARRAES, N. A. M. Análise de Hortas Comunitárias em Campinas/SP. Organizações Rurais \& Agroindustriais, Lavras, v. 9, n. 1, p. 38-52, 2007. Disponível em: <http://ageconsearch.umn.edu/bitstream/43795/2/(03)\%20Artigo\%2006.272.pdf>. Acesso em: 15 fev. 2012.

BARROS, C. De rural a rururbanos: transformaciones territoriales y construcción de lugares al Sudoeste del área metropolitana de Buenos Aires. Scripta Nova, Barcelona, v. 51, n. 45, ago. 1999. Disponível em: 〈http://www.ub.edu/geocrit/sn-45-52.htm>. Acesso em: 21 fev. 2012.

BONI, S. J.; QUARESMA, S. J. Aprendendo a entrevistar: como fazer entrevistas em Ciências Sociais. Revista Eletrônica dos Pós-Graduandos em Sociologia Política da UFSC. Florianópolis, v.2 n.1 (3), janeiro-julho/2005. Disponível em: <http://www.emtese.ufsc.br/3_art5.pdf $>$. Acesso em: 10 de maio de 2011.

BOVO, M. C.; AMORIM, M. C. de C. T. Análise e diagnóstico de parques urbanos em Maringá (PR). Geo UERJ. Rio de Janeiro, ano. 13, v.2, p. 323-349, agosto-dez, 2011. Disponível em: <http://www.epublicacoes.uerj.br/index.php/geouerj/article/view/2466/1737>. Acesso em: $14 \mathrm{de} \mathrm{fev} \mathrm{de}$ 2012.

DIAS, C. S.; DIAS, S. I. S. Urbano e Regional: Ensaios Acadêmicos do CAUFAG 2008. Belém do Pará: História, Urbanismo e Identidade. 2007. Cascavel: Smolarek Arquitetura. Disponível em: $<$ http://www.fag.edu.br/professores/solange/PRODUCAO\%20CIENTIFICA/5\%BA\%2 0ECCI/BEL\%C9M\%20DO\%20PAR\%C1\%20-\%20Caio.pdf>. Acesso em 20 fev. 2012.

EDITORES DO PUBLICATIONS INTERNATIONAL. UOL. Como desenhar paisagens. Disponível em: <http://lazer.hsw.uol.com.br/como-desenhar.htm>. Acesso em 20 jan. 2012.

FERREIRA, R. J.; CASTILHO, C. J. M. de. Agricultura Urbana: discutindo algumas das engrenagens para debater o tema sob a ótica da análise espacial. CampoTerritório: Revista de Geografia, Recife, v. 24, n. 2, p. 06-23, mai/ago. 2007. Disponível em: <http://www.ufpe.br/revistageografia/index.php/revista/article/viewFile/111/66 > . Acesso em: 15 fev. 2012.

FONTOURA, L. F. M. A relação campo-cidade como método. In: MEDEIROS, R. M. V.; FALCADE, I. (Orgs.). Tradição versus tecnologia: as novas territorialidades do espaço agrário brasileiro. Porto Alegre: Ed. da UFRGS, 2009. p. 269-284. 
FROIE GRÁS COM DENDÊ. Maxixe. Disponível em: <http://foiegrascomdende.blogspot.com/2011/05/maxixe-revista-muito-receitas.html>. Acesso em 26 jan. 2012.

GHIGLIONE, R.; MATALON, B. O inquérito. Teoria e prática. 3. ed. Oeiras: Celta, 1997.

GORENSTEIN, S; NAPAL, M.; OLEA, M. Territorios agrários y realidades rururbanas. Reflexiones sobre el desarollo rural a partir del caso pampeano bonaerense. Revista EURE, Santiago do Chile, v. 33, n. 100, p. 91-113, dez. 2007. Disponível em: $<$ http://www.scielo.cl/scielo.php?pid=S0250-71612007000300006\&script=sci_arttext $>$. Acesso em: 15 fev. 2012.

HÉBETTE, J.; MARIN, R. E. A. A ligação rodoviária Norte-Sul: Sonhos e Realidade. In: HÉBETTE, J. Cruzando a Fronteira. 30 anos de estudo do campesinato na Amazônia. Belém do Pará: Ed. da UFPA, v. 1, 2004. p. 35-40.

HÉBETTE, J.; MARIN, R. E. A. Colonização Espontânea, Política Agrária e Grupos Sociais. In: HÉBETTE, J. (Org.). Cruzando a Fronteira. 30 anos de estudo do campesinato na Amazônia. Belém do Pará: Ed. da UFPA, v. 1, 2004. p. 41-73.

IZQUIERDO, J.; GRANADOS, S. Agricultura urbana y periurbana como alternativa para mejorar la calidad de vida de lãs famílias vulnerables: respuesta al alza de los precios de los alimentos. In: GRAZIANO DA SILVA, J. Políticas de reemplazo de importaciones agrícolas. Santiago: FAO, 2009.

KOZENIESKI, É. de M. O rural agrícola na metrópole: o caso de Porto Alegre/RS. 2010. 130f. Dissertação (Mestrado em Geografia) - Universidade Federal do Rio Grande do Sul, Porto Alegre, 2010.

LEFEBVRE, H. A revolução urbana. Belo Horizonte: Ed. da UFMG, 1999.

LINDNER, M.; WANDSCHEER, E. A. R. Manifestações das ruralidades em pequenos municípios gaúchos: o exemplo da Quarta Colônia de Imigração Italiana. CampoTerritório: Revista de Geografia Agrária, Uberlândia, v. 5, n. 9, p. 147-165, fev. 2010. Disponível

em: 〈http://www.seer.ufu.br/index.php/campoterritorio/article/view/11960/6986>. Acesso em: 16 fev. 2012.

MADALENO, I. R. A cidade das mangueiras: agricultura urbana em Belém do Pará. Portugal: Fundação Calouste Gulbenkian e Fundação para a Ciência e a Tecnologia, 2002.

MONDARDO, M. L. Manifestações das ruralidades em pequenos municípios gaúchos: o exemplo da Quarta Colônia de Imigração Italiana. Campo-Território: Revista de Geografia Agrária, Uberlândia, v.3, n. 5, p. 114-137, fev. 2008. Disponível em: 
<http://www.seer.ufu.br/index.php/campoterritorio/article/view/11849/6935>. Acesso em: 16 fev. 2012.

OLIVEIRA, F. L. de. Vitruvirus. Arquitextos. Disponível em: $\langle$ http://vitruvius.com.br/revistas/read/arquitextos/10.120/3433 $>$. Acesso em $20 \mathrm{jan}$. 2012.

OLIVEIRA, F. L. de. A Margem e o Centro na Produção do Urbano na Amazônia. In: SIMONIAN, L. T. L. (Org.). Belém do Pará: História, Cultura e Sociedade. Belém do Pará: Ed. do NAEA, 2010. p. 33-48.

ORGANIZAÇÃO DAS NAÇÕES UNIDAS PARA A AGRICULTURA E A ALIMENTAÇÃO - FAO. Agriculura Urbana e Periurbana como ferramenta para a segurança alimentar e o desenvolvimento territorial. Santiago do Chile, 2009. CDROM.

PEREIRA, J. C. M. A Urbanização da Amazônia e o papela das Cidades Médias na Rede Urbana Regional. In: CARDOSO, A. C. D. (Org.). O Rural e o Urbano na Amazônia. Diferentes Olhares em Perspectivas. Belém do Pará: Ed. da UFPA, 2006. p. 23-54.

PLANTAS MEDICINAIS \& FITOTERAPIA. Arquitextos. Disponível em: $<$ http://vitruvius.com.br/revistas/read/arquitextos/10.120/3433>. Acesso em 20 jan. 2012.

PORTAL SÃO FRANCISCO. Açaí: benefícios do suco, fruta e da polpa de Açaí. Disponível em: <http://www.plantasmedicinaisefitoterapia.com/plantas-medicinaisacai.html $>$. Acesso em 26 jan. 2012.

PRIEB, R. I. P. A pluriatividade na produção familiar fumageira. Santa Cruz do Sul: EDUNISC, 2005.

RICHARDSON, R. J. Pesquisa social: Métodos e Técnicas. 3 ed. São Paulo: Atlas, 1999.

ROESE, A. D. Agricultura Urbana. Rural Centro. Brasília: EMBRAPA, s/d. Disponível em: <http://www.ruralcentro.com.br/Sistema/Noticias.aspx?ID=5895>. Acesso em 10 jun. 2009.

RUA, J. Urbanidades no Rural: o devir de novas territorialidades. Campo-Território: Revista de Geografia Agrária, Uberlândia, v. 1, n. 1, p. 82-106, fev. 2006. Disponível em: 〈http://www.campoterritorio.ig.ufu.br/viewarticle.php?id=23 > . Acesso em: 15 fev. 2012.

SANTANDREU, A.; LOVO, I. C. Panorama da Agricultura Urbana e Periurbana no Brasil e diretrizes políticas para sua promoção. Identificação e Caracterização de Iniciativas de AUP em Regiões Metropolitanas Brasileiras. Disponível em: < 
http://www.unama.br:8080/Colunas/ServletVerArquivo?idColuna=301>. Acesso em 15 fev. 2012.

SANTOS, M. Economia espacial. 2. ed. São Paulo: EDUSP, 2007.

Os Dois Circuitos da Economia Urbana e suas Implicações Espaciais. São Paulo: EDUSP, 2008.

Pobreza urbana. 3. ed. São Paulo: EDUSP, 2009a.

Por uma economia política da cidade. 2. ed. São Paulo: EDUSP, 2009 b.

SANTOS M. A. S. dos.; SILVA, M. Y. C. da. Agricultura Urbana e Periurbana na região metropolitana de Belém: um estudo exploratório com produtores de hortaliças no município de Marituba. Produção Científica. 2010. Disponível em: $<$ http://www.unama.br:8080/Colunas/ServletVerArquivo?idColuna=301 >. Acesso em: 15 fev. 2012.

SCHNEIDER, S. A pluriatividade na agricultura familiar. Porto Alegre: Ed. da UFRGS, 2003.

SILVA, S. B. de. Belém e o ambiente insular. Belém do Pará: Ed. da UFRA, 2010.

VEIGA, J. E. da. A história não os absolverá nem a geografia. Campinas: Autores Associados, 2005.

Cidades imaginárias o Brasil é menos urbano do que se calcula. 2. ed. Campinas: Autores Associados, 2003.

WANDERLEY, M. de N. B. O mundo rural como um Espaço de vida. Reflexões sobre a propriedade da terra, agricultura familiar e ruralidade. Porto Alegre: Ed. da UFRGS, 2009.

Artigo encaminhado para publicação em abril de 2012.

Artigo aceito para publicação em maio de 2012. 